\title{
Role of elevated serum Adiponectin in delayed puberty of Thalassemic patients
}

\author{
Mohamed A. Mekawey, Soha R. Youssef, Mahera I. Almogy, ${ }^{*}$ Merhan S. Nasr, ${ }^{* *}$ Nevine Gamal, Nagwa \\ K. Ragheb
}

Departments of Clinical Pathology, *Internal Medicine and ** Pediatrics, Ain Shams University Hospital, Cairo, Egypt

\section{Objectives:}

Thalassemia is the most common genetic disorder worldwide occurring approximately in 4.4 of every 10,000 live births. Blood transfusion which is critical for survival of thalassemic patients is a double wedge sword. It prolongs life while it eventually leads to iron overload. This results in various endocrinal dysfunctions which lead to high incidence of growth retardation and delayed puberty.1 It has been suggested that adipose tissue dysfunction can play a role in the neuroendocrine and haematopoietic dysfunctions affecting thalassaemic patients. ${ }^{2}$ In this work, we aimed to study the serum levels of adiponectin, an adipocytokine, in Egyptian beta thalassemia patients in relation to their endocrinal complications.

\section{Methods:}

\section{Results:}

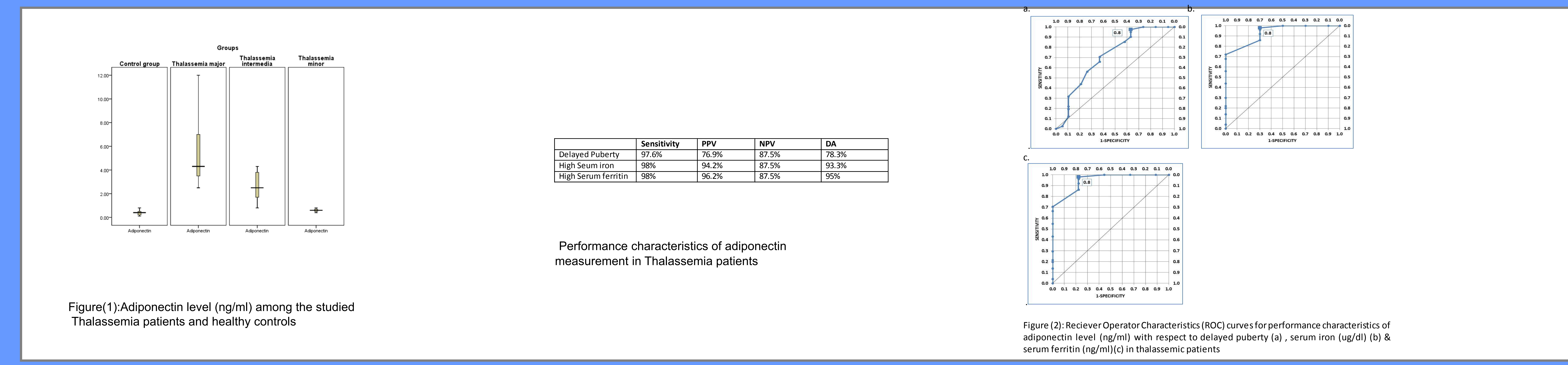

The study included $60 \beta$ - thalassaemia patients; (major, intermedia \& minor) and 30 healthy age- and sex-matched controls. The diagnosis of Thalassemia was based on clinical, haematological, and genetic studies. Anthropometric measurements (BMI and Z score), clinical neuroendocrinal assessment (Tanner staging), Iron profile (serum Ferritin, serum iron and total iron binding capacity) and measurment of serum levels of adiponectin using Enzyme Linked Immuno Sorbant Assay were performed for all subjects.

A significantly higher level of adiponectin was found in thalassemic patients (median $=3.5 \mathrm{ng} / \mathrm{ml}$ ) compared to controls (median $=0.4 \mathrm{ng} / \mathrm{ml}$ ) with the level becoming progressively higher with degree of clinical severity (median= $0.6 \mathrm{ng} / \mathrm{ml}$ in minor, $2.5 \mathrm{ng} / \mathrm{ml}$ in intermedia \& $4.3 \mathrm{ng} / \mathrm{ml}$ in major). The level of adiponectin was negatively correlated to height, weight \& BMI in both Thalassemia intermedia \& major while it was negatively correlated to puberty only in Thalassemia major patients. A clinically significant level of adiponectin was obtained at $>0.8 \mathrm{ng} / \mathrm{ml}$ for delayed puberty \& iron overload (high serum iron $\&$ serum ferritin).

1-Merehamr RH, Shirodkar A and Ahmed J 2011 Evaluation of growth, puberty and endocrine dysfunction in relations to iron overload in multitransfused Indian thalassemia patients. Indian $\mathrm{J}$ Pediatotr 78 (6): 679-683

2-Chaliasos N, Challa A, Hatzimichae E, Koutsouka F, Bouranta D, Vlahos AP, Siamopoulou A, Bourantas DK, Siamopoulou A, Bourantas KL and Makis A 2010 Serum Adipocytokine and Vascular Inflammation Marker Levels in Beta-Thalassaemia Major Patients Acta Haematol 124:191-196 